\title{
Economic and Practical Factors in Diagnosing HNPCC Using Clinical Criteria, Immunohistochemistry and Microsatellite Instability Analysis
}

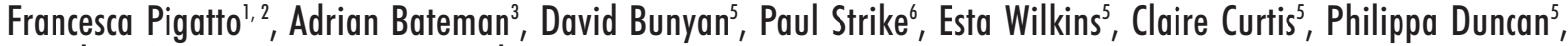 \\ Denzil May ${ }^{3}$, Karen Nugent ${ }^{4}$, Diana Eccles ${ }^{1,5}$ \\ 'Wessex Clinical Genetics Service, Princess Anne Hospital, Southampton S016 5YA, UK; ${ }^{2}$ Division of Chemoprevention, European Institute of Oncology, via Ripamonti, \\ Milan, Italy; ${ }^{3}$ Department of Cellular Pathology; ${ }^{4}$ Department of Surgery, Southampton University Hospitals NHS Trust, Southampton S016 6YD, UK; ${ }^{5}$ Wessex Regional \\ Genetics Laboratory and 6Medical Statistics RDSU, Salisbury District Hospital, Salisbury, Wiltshire SP2J 8B, UK
}

Key words: HNPCC, mutation analysis, clinical criteria, immunohistochemistry, microsatellite instability, cost analysis

Corresponding author: Dr Diana Eccles, Wessex Clinical Genetics Service, Level G, Princess Anne Hospital, Southampton S016 6YA, tel. 0238079 8537, fax 0238079 4346,e-mail: del@soton.ac.uk

Submitted: 13 August 2004

Accepted: 5 November 2004

\begin{abstract}
Aim: To determine a cost-efficient strategy for HNPCC molecular diagnostic testing.

Methods: 138 families referred to a Regional Genetics Service had hMLH1 and hMSH2 mutation analysis. The sensitivity and specificity of clinical selection criteria with or without immunohistochemistry (IHC) and microsatellite instability (MSI) analysis to further refine case selection and the effect of these approaches on the cost of mutation analysis were examined.

Results: Clearly deleterious mutations were identified in 49/138 (35.5\%) of all families tested. The most sensitive criteria for identifying families with MMR mutations were the full Bethesda guidelines but these have poor specificity. IHC and MSI were useful pre-screening tools.

Conclusion: A cost-efficient approach in laboratories where IHC and/or MSI analysis are available, is to use inclusive (non-specific) criteria to select cases, followed by IHC and then MSI. Where one or both results are abnormal, proceed to further mutation analysis. Where MSI or IHC or tumour blocks are not available, more restrictive clinical criteria may be more appropriate for cost-efficient case selection.
\end{abstract}

\section{Introduction}

Hereditary non-polyposis colorectal cancer (HNPCC) accounts for around 2-3\% of all colorectal cancers and is an autosomal dominant cancer predisposition syndrome caused primarily by inactivating mutations in one of the genes involved in DNA mismatch repair (MMR), most commonly MLH1 and MSH2 [1, 2, 3]. HNPCC is characterised clinically by an early age of onset, a predominance of right-sided tumours and a high frequency of synchronous and metachronous cancers.
It is important to diagnose HNPCC because colonoscopic surveillance with removal of adenomas and detection of early carcinomas reduces the colorectal cancer (CRC) rate and overall mortality in HNPCC mutation carriers [4].

DNA analysis in many diagnostic laboratories has concentrated on the two most frequently affected genes, hMLH1 and hMSH2. Both are moderately large genes and mutations are scattered throughout making mutation searching expensive. The benefits of finding a pathogenic mutation are clear; colonoscopy 
screening can be directed towards family members at high risk and low risk family members can be discharged from screening. Because mutation analysis techniques are not 100\% sensitive and because HNPCC is heterogeneous, a "negative" result from a mutation search is essentially unhelpful. For this reason mutation analysis is not usually recommended in individuals with a very low probability of carrying a mutation. Practical methods of pre-selection before DNA analysis would allow a reduction of mutation analysis costs without a significant loss of sensitivity in the identification of alterations within the $\mathrm{MLH1}$ and $\mathrm{MSH} 2$ genes and allow a more cost-effective implementation of genetic testing particularly in the lower probability clinical categories (for example isolated early onset colorectal cancer). In the diagnostic laboratory we have examined the feasibility of pre-selection using a range of published clinical criteria, microsatellite instability (MSI) analysis and immunohistochemistry (IHC) to look for loss of DNA mismatch repair enzyme expression.

Assessment of family pedigree is the usual method for classifying the likelihood that a patient will have a germline MMR gene mutation [5]. Several clinical diagnostic criteria have been proposed to identify families with HNPCC (Table 1). The earliest published clinical criteria are the Amsterdam criteria initially coined to help select families for linkage studies [6]. However, these are restrictive, identifying only a small proportion of families with detectable mutations because of the requirement for three first-degree relatives with colorectal cancer and the exclusion of extracolonic tumours [7]. The Modified Amsterdam criteria [8], the Bethesda guidelines [9], and more recently the Amsterdam II criteria [10] followed this as more sensitive clinically useful criteria. The Bethesda criteria have recently been revised [11] but for the purposes of this analysis the original Bethesda guidelines have been used for classification of cases.

Microsatellite instability (MSI) has been detected in $90 \%$ of tumours with a germline MMR mutation and is considered to be a key feature of HNPCC $[12,13]$. However, MSI also occurs in at least $15 \%$ of sporadic colorectal cancers, usually due to hypermethylation of the promoter sequence of one of the MMR enzyme-encoding genes, usually hMLH1 [14].

A reference panel of five microsatellite markers (BAT26, BAT25, D2S123, D5S346, and D17S250) has been standardised by the National Cancer Institute for the screening of colorectal cancer [15]. In our study we used only BAT26, a poly (A) tract located in the fifth intron of $\mathrm{MSH} 2$, because the cost of analysis worked out at a similar cost to $\mathrm{IHC}$ for the purposes of a comparison. Also BAT26 appears to have some advantages over many other markers as it is easy to use and has been reported to be extremely sensitive in detecting tumours with instability [16-18]. BAT26 alleles show only minor size variations not exceeding two base pairs from one cell line to another, thus seeming monomorphic or quasi-monomorphic. In addition the

Table 1. Clinical criteria for identifying families with HNPCC

\begin{tabular}{|c|c|}
\hline Amsterdam & $\begin{array}{l}\text { Three relatives with colorectal cancer }(C R C) \text {, one of whom is a first-degree relative of the other two; } C R C \text { involving } \\
\text { at least two generations; one or more } C R C \text { cases diagnosed before the age of } 50 \text { years. }\end{array}$ \\
\hline $\begin{array}{l}\text { Modified } \\
\text { Amsterdam }\end{array}$ & $\begin{array}{l}\text { Very small families, which cannot be further expanded, can be considered as HNPCC even if only two CRCs } \\
\text { in first-degree relatives; CRC must involve at least two generations, and one or more CRC cases must be diagnosed } \\
\text { before the age of } 55 \text { years. } \\
\text { OR two first-degree relatives affected by CRC and the presence of a third relative with an unusual early } \\
\text { onset neoplasm or endometrial cancer }\end{array}$ \\
\hline Amsterdam II & $\begin{array}{l}\text { Three relatives with an HNPCC-associated tumour (CRC, endometrial, small bowel, ureter or renal pelvis), } \\
\text { one of whom is the first-degree relative of the other two; involving at least two generations; } \\
\text { one or more cases diagnosed before the age of } 50 \text { years. }\end{array}$ \\
\hline Bethesda & $\begin{array}{l}1 \text { - Subjects with cancer in families that fulfil the Amsterdam criteria. } \\
2 \text { - Subjects with two HNPCC-related cancers, including synchronous and metachronous CRCs or associated extracolonic } \\
\text { cancers. } \\
3 \text { - Subjects with CRC and a first-degree relative with CRC and/or HNPCC-related extracolonic cancers and/or colorectal } \\
\text { adenoma(s); one of the cancers diagnosed at age }<45 \text { years and the adenoma(s) diagnosed at age }<40 \text { years. } \\
4 \text { - Subjects with CRC or endometrial cancer diagnosed at age }<45 \text { years. } \\
5 \text { - Subjects with right-sided CRC with an undifferentiated pattern (solid/cribriform) on histopathology diagnosed at age } \\
\quad<45 \text { years. } \\
6 \text { - Subjects with signet ring cell type CRC diagnosed at age }<45 \text { years. } \\
7 \text { - Subjects with colorectal adenoma(s) diagnosed at age }<40 \text { years. }\end{array}$ \\
\hline
\end{tabular}



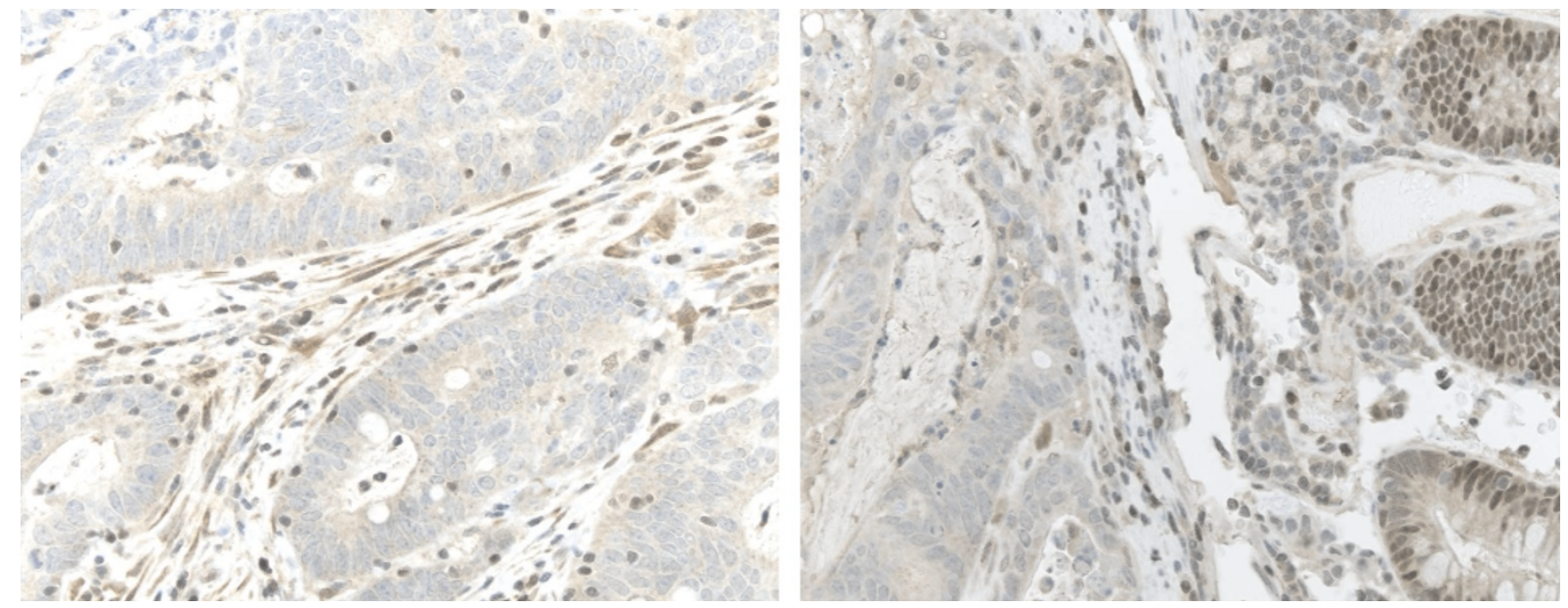

Fig. 1. IHC using antibodies to MSH2 (a) and MLH1 (b)

stability of BAT26 in the Caucasian population where any polymorphism is rare potentially allows the determination of tumoural microsatellite instability without reference to germline DNA. This approach was therefore chosen as it could potentially be set up routinely in any diagnostic pathology laboratory for pre-screening for example all colorectal cancer samples under 50 years of age.

Loss of MLH1 or MSH2 protein expression in tumour tissue, due to mutation and/or inactivation of both copies of the gene involved, can be detected by immunohistochemistry $(\mathrm{IHC})$, using commercially available antibodies. $\mathrm{IHC}$ for $\mathrm{MLH} 1$ and $\mathrm{MSH} 2$ proteins has a high sensitivity and predictive value in detecting MMR deficient cancers and therefore offers an alternative strategy for selecting HNPCC families [19, 20]. IHC can suggest the presence of a mutation within a specific MMR-encoding gene and therefore directs germline mutation analysis to a single potentially affected gene, saving unnecessary mutation analysis.

The aim of this study was to determine the most cost-effective strategy for the detection of MMR gene mutations in cases referred to our regional clinical genetics service.

\section{Materials and methods}

\section{Patients}

Pedigree and clinical data were collected for a series of 138 families referred to our regional genetics service between 1996 and 2002. Our guidelines for referral were equivalent to the Bethesda guidelines. We classified each pedigree for the purposes of this analysis using the established clinical criteria (Amsterdam, Amsterdam II, Modified Amsterdam criteria and Bethesda guidelines). DNA extracted from peripheral white blood cells (PBLs) from a single proband in each family was used for mutation analysis. Tumour blocks were requested for all cases but material for only 55 cases was available.

\section{Immunohistochemistry}

For each sample, eight sections (3-4 $\mu \mathrm{m})$ were cut and mounted onto glass slides. After dewaxing and rehydration of sections, antigenic site retrieval was accomplished by microwaving each slide for five minutes in $0.01 \mathrm{M}$ citric acid buffer ( $\mathrm{pH}$ 6.0). Endogenous peroxidase activity was blocked by incubation with $2 \%$ hydrogen peroxide for 20 minutes and non-specific binding prevented by incubation with $1 \%$ bovine serum albumin (BSA) in phosphate buffered saline (PBS). Sections were subsequently incubated with either monoclonal antiMLH1 or anti-MSH2 antibodies (Oncogene, Cambridge, Massachusetts, USA) for two hours at room temperature. Antibody binding was detected using the Ellite Vectastain ABC kit (Nector Laboratories Ltd, Peterborough, UK), using the manufacturer's protocol. The reaction was visualised using a VIP substrate kit for peroxidase (Vector Laboratories Ltd). Sections were then dehydrated and mounted. Normal colonic crypt epithelium taken from tissue adjacent to the tumour served as an internal positive control. In almost all cases, staining was observed in only some areas of the tumour or control sections. Loss of expression was recorded when nuclear protein expression was observed in normal tissues and tumour-associated stroma but not within malignant epithelial cells (i.e. carcinoma cells). Examples are shown in Fig. 1. 


\section{Microsatellite instability (MSI)}

Tumour DNA samples obtained from paraffin sections were analysed for MSI using the BAT26 marker. Six (5 $\mu \mathrm{m})$ thick tissue sections were dewaxed and dried to form a pellet which was then processed according to the tissue protocol (QIAamp DNA mini kit handbook - Qiagen) to yield DNA. PCR amplification was carried out in a 25 $\mu$ reaction volume containing 50-100 ng of genomic DNA, 10 x PCR buffer, 0.2 mM dNTPs (Promega), 0.2 $\mu \mathrm{M}$ each primer, and 0.5 units of Hotstar taq polymerase (Qiagen). The final $\mathrm{MgCl}_{2}$ concentration was $2.5 \mathrm{mM}$. [PCR cycles: $95^{\circ} \mathrm{C}$ for 15 minutes, 35 cycles at $94^{\circ} \mathrm{C}$ for 30 seconds, $50^{\circ} \mathrm{C}$ for 30 seconds and $72^{\circ} \mathrm{C}$ for 30 seconds, followed by $72^{\circ} \mathrm{C}$ for 7 minutes and finally $60^{\circ} \mathrm{C}$ for 60 minutes]. PCR products were run on an ABI 3100 genetic analyser (Applied Biosystems Perkin Elmer). Microsatellite instability was defined as the presence of altered allele sizes in the PCR-amplified product of tumour DNA compared with the PCR-amplified product from the genomic DNA sample of the same individual.

\section{Mutation analysis}

DNA was extracted from PBLs using standard techniques. Genomic DNA (100ng) was amplified using a combination of the primers and conditions listed by Holinski-Feder et al [21] as well as some primers designed in house. Initially heteroduplex analysis was used and subsequently superseded by dHPLC. MLPA were used in the remaining cases where a pathogenic mutation had not already been detected.

\section{PCR amplification and heteroduplex formation}

PCR reactions were carried out in a total volume of $25 \mu \mathrm{l}$ : each reaction contained $2.5 \mu \mathrm{l}$ Gene Amp 10x Buffer II (no $\mathrm{MgCl}_{2}$ ), $2.5 \mu \mathrm{l} 25 \mathrm{mM} \mathrm{MgCl} 2,2.5 \mu \mathrm{l}$ of 2 mM dNTP mix, $0.1 \mu$ of AmpliTaq Gold ${ }^{\text {TM }}$ (PE Applied Biosystems, Foster City, California, USA), $10.4 \mu$ sterile distilled water, $1.0 \mu \mathrm{l}$ of each $10 \mathrm{nM}$ primer and $50 \mathrm{ng}$ of DNA. [PCR cycles: $95^{\circ} \mathrm{C}$ for 15 minutes, 35 cycles consisting of $95^{\circ} \mathrm{C}$ denaturation for 30 seconds, annealing at $53^{\circ} \mathrm{C}$ or $60^{\circ} \mathrm{C}$ for 45 seconds, and extension at $72^{\circ} \mathrm{C}$ for 45 seconds, followed by a final extension at $72^{\circ} \mathrm{C}$ for 7 minutes]. Prior to analysis the PCR products were heteroduplexed at $95^{\circ} \mathrm{C}$ for 5 minutes with a reduction of $1.5^{\circ} \mathrm{C}$ per cycle for 45 cycles.

\section{Heteroduplex analysis}

$10 \mu$ of PCR product was run overnight on a 24 $\mathrm{cm}$ Hydrolink gel (AT Biochem). Heteroduplex bands were visualized by ethidium bromide staining.

\section{dHPLC analysis}

The Transgenomic Wave ${ }^{\circledR}$ DNA Fragment Analysis System (Transgenomic Inc, San Jose, California, USA) was used for the DHPLC analysis. This included a DNA Sep ${ }^{\circledR}$ polystyrene-divinyl benzene $\mathrm{C} 18$ column as the stationary phase, and a mobile phase consisting of $(A)$ $0.1 \mathrm{M}$ Triethylammonium acetate (TEAA) and (B) 0.1 M TEAA-25\% Acetonitrile (ACN) and a UV detector set at $260 \mathrm{~nm}$. The products were analysed using a range of partial denaturing temperatures established using Transgenomic Wave maker software version 3.4, with a flow rate of $0.9 \mathrm{ml} / \mathrm{min}$ and linear gradients of $B$ increasing by $2 \%$ per minute.

\section{Multiplex Ligation Probe Assay}

Multiplex Ligation Probe Assay (MLPA) was performed using kit P003 from MRC-Holland (Amsterdam, The Netherlands). MLPA PCR products were separated on an ABI 3100 machine and analysed using Genotyper version 2.0 (Perkin-Elmer). Peak heights from each patient were then compared to those of normal control individuals using an Excel spreadsheet to assess the ratios of each test peak relative to the corresponding peaks in the control patients.

\section{Sequence analysis}

PCR products were sequenced in forward and reverse directions using BigDye ${ }^{\circledR}$ Terminator $v 1.1$ chemistry (Applied Biosystems). Samples underwent 25 cycles of amplification $\left(30\right.$ seconds at $96^{\circ} \mathrm{C}, 15$ seconds at $50^{\circ} \mathrm{C}$, 2 minutes at $60^{\circ} \mathrm{C}$ ). Excess terminators were removed using DyeEx ${ }^{\mathrm{TM}} 2.0$ spin columns (Qiagen) prior to running on an $A B I 3100$ genetic analyser.

\section{Statistical analysis}

The sensitivity and specificity for each set of clinical criteria as a means of identifying families with an inherited MMR-encoding gene mutation were calculated using $2 \times 2$ tables. The sensitivity of each set of criteria was defined as the proportion of patients with a mutation in MLH1 or MSH2 who met those clinical criteria i.e. those who would be "correctly" selected for mutation testing using these clinical criteria (sensitivity [\%] = true positives/[true positives + false negatives] $x$ 100). The specificity of each set of criteria was defined as the proportion of patients who did not have a mutation in MLH1 or MSH2 or who did not fulfil those clinical criteria i.e. those who would be correctly excluded from mutation testing using these criteria (specificity [\%] = true negatives/[true negatives + false positives] $\times 100$ ). 
95\% confidence intervals were calculated using StatXact version 4 software (Cytel Software Corporation). The predictive value of the clinical criteria was estimated using the observation that the prevalence of gene mutations in the whole target group is 49/138 (35.5\%) and gives a measure of the overall performance of each of the criteria used for selection.

\section{Cost analysis - strategies examined}

1. Clinical criteria only, full mutation analysis on both $\mathrm{MLH} 1$ and MSH2 genes.

2. Using $\mathrm{IHC}$ to determine which gene to test and testing only the cases with abnormal protein expression.

3. Using MSI testing followed by full mutation analysis on both genes, where BAT26 was unstable.

4. Using $\mathrm{HC}$ then if normal (no loss) MSI analysis, then mutation analysis if either result abnormal.

The costs of the analyses used for the calculations were based on charges in our diagnostic laboratories: IHC - 50 euros, MSI - 50 euros (BAT26 only), Mutation analysis - 500 euros per gene analysed.

\section{Results}

A total of 138 families were included. 53 families fulfilled the Amsterdam criteria, 65 fulfilled the Modified Amsterdam criteria, 68 fulfilled Amsterdam II criteria and 134 fulfilled the Bethesda guidelines. The search for germline mutations in MLHI and MSH2 was performed initially using PCR amplification and heteroduplex analysis; 133 patients subsequently underwent $\mathrm{AHPLC}$ analysis. MLPA analysis was carried out on 99 patients (including all cases where a mutation had not been detected using the other techniques).

The mutations found in the MLH1 and MSH2 genes along with the results of MSI and $\mathrm{IHC}$ are summarised in Tables $2 a$ and $2 b$.

Clearly deleterious mutations were found in 49 of the 138 families (35.5\%): 20 in MLH1 and 29 in MSH2 (18 frameshift, 10 nonsense, 9 splice site mutations, 7 large deletions and 5 missense mutations). For the 5 missense mutations, four had evidence of loss of MLHI expression and for the fifth where tissue blocks were not available, clear evidence of segregation of the mutation with tumour predisposition was found. Additional six families were found to have mutations of unclear significance: 5 missense mutations and one inframe deletion. Only clearly deleterious mutations were counted for the purposes of this analysis.

\section{Sensitivity and specificity of clinical criteria (Table 3)}

The most sensitive criteria were the Bethesda criteria 1 to $3(92 \%)$ but these criteria had relatively low specificity at $39 \%$. The small increase in sensitivity from adding the Bethesda 4 to 7 criteria resulted in an overall large reduction in specificity to $2 \%$. The Amsterdam II criteria performed well in this series for both sensitivity $(80 \%)$ and specificity $(69 \%)$ with similar figures for Amsterdam and modified Amsterdam categories.

\section{Mutation testing strategy analysis}

Both $\mathrm{IHC}$ for MSH2 and MLH1 and MSI analysis with the BAT26 marker were available in 55 of 138 patients. Pathogenic mutations were identified in 16/55 (29\%). In further 4 cases, previously extracted pathology DNA was available but not tumour blocks and in 9 cases we had IHC data but MSI analysis was unsuccessful. Sensitivity for $\mathrm{IHC}$ was $84 \%$ (62\% to $96 \%$ ) and for MSI was $68 \%$ ( $43 \%$ to $87 \%)$.

\section{Cost analysis}

Proceeding directly to mutation analysis was the most expensive option for all clinical criteria. IHC greatly reduced the cost of mutation detection due to only needing to analyse one of the two genes in cases with an informative result (loss of protein expression). Three mutations were missed out of twenty one mutations found where $\mathrm{IHC}$ was tested, all of the missed mutations were in the hMLH1 gene (clinical criteria were Amsterdam (1) and Bethesda 1 to 3 (2)). MSI alone, using BAT26 as the only marker of instability, had a lower ability compared with IHC to predict the presence of a mutation. Where both MSI and IHC data were available the maximum sensitivity was gained with only a modest increase in cost above that using $\mathrm{IHC}$ alone. If only one technique were available, $\mathrm{IHC}$ would be more cost effective than MSI analysis. Table 4 summarises the cost analyses for the possible strategies considered.

\section{Discussion}

Our study shows that by combining IHC and MSI analysis with clinical criteria, the cost of mutation detection can be reduced without lowering the mutation detection rate. Our results have implications for routine diagnostic genetics services where the capacity for mutation testing is constrained by the rate of throughput and available funding within a nationally funded health care service. The proposed strategy requires that tumour tissue is made freely available. 
Table 2a. Detected MHL1 mutations, clinical criteria and results of MSI and IHC analyses

\begin{tabular}{|c|c|c|c|c|c|c|c|c|}
\hline $\begin{array}{l}\text { clinical } \\
\text { criteria }\end{array}$ & $\begin{array}{l}\text { colon } \\
\text { cancer } \\
\text { total }\end{array}$ & $\begin{array}{c}\text { colon } \\
\text { cancer } \\
\text { average }\end{array}$ & $\begin{array}{c}\text { MS } \\
\text { status } \\
\text { age }\end{array}$ & $\begin{array}{c}\text { loss } \\
\text { MLH1 } \\
\text { expression }\end{array}$ & $\begin{array}{c}\text { loss } \\
\text { MSH2 } \\
\text { expression }\end{array}$ & $\begin{array}{l}\text { mutation } \\
\text { type }\end{array}$ & pathogenic & $\begin{array}{c}\text { MLH1 } \\
\text { mutation }\end{array}$ \\
\hline A & 4 & 46 & ND & Yes & No & missense & yes & $350 C>T$ \\
\hline A & 3 & 34 & MSI & No & No & frameshift & yes & $1821 \mathrm{ins} T$ \\
\hline A & $\sim 7$ & $\mathrm{NK}^{*}$ & ND & ND & ND & frameshift & yes & 11379-1380delAG \\
\hline A & 4 & 54 & MSI & ND & ND & stop & yes & $2135 G>A$ \\
\hline A & 5 & 35 & ND & ND & ND & frameshift & yes & 1492insG \\
\hline A & 4 & 37 & MSI & Yes & No & stop & yes & $2250 C>A$ \\
\hline A & 9 & 45 & MSS & Yes & No & missense & yes & $122 A>G$ \\
\hline A & 3 & 35 & ND & ND & ND & frameshift & yes & 735 delC \\
\hline A & 3 & 32 & ND & ND & ND & missense & yes & $199 \mathrm{G}>\mathrm{A}$ \\
\hline A & 4 & 43 & MSI & ND & ND & stop & yes & $1459 C>T$ \\
\hline A & 6 & 46 & ND & ND & ND & frameshift & yes & 105insAAA \\
\hline A & 3 & 54 & MSI & Yes & No & frameshift & yes & 2252-2253delAA \\
\hline B 1-3 & 2 & 61 & MSI & No & No & splice & yes & $1989+1 G>A$ \\
\hline B $1-3$ & 2 & 39 & MSI & Yes & No & missense & yes & $350 C>T$ \\
\hline B $1-3$ & 1 & 30 & MSS & No & No & missense & NK & $110 A>G$ \\
\hline B $1-3$ & 1 & 48 & ND & No & No & stop & yes & $2250 C>A$ \\
\hline B $1-3$ & 2 & 34 & ND & ND & ND & missense & yes & $350 C>T$ \\
\hline$B 1-3$ & 1 & 62 & ND & ND & ND & stop & yes & $1849 A>T$ \\
\hline B4-7 & 1 & 28 & MSI & Yes & No & inframe & NK & 1854-1856delAAG \\
\hline B4-7 & 1 & 35 & MSI & Yes & No & splice & yes & $588+1 G>A$ \\
\hline MA & 2 & 42 & ND & No & Yes & missense** & no & $2125 G>A$ \\
\hline MA & 2 & 45 & ND & ND & ND & missense & NK & $2041 G>A$ \\
\hline MA & 3 & 59 & ND & ND & ND & splice & yes & 2104-1delGAG \\
\hline MA & 2 & 43 & ND & ND & ND & splice & yes & $677 G>A$ \\
\hline
\end{tabular}

Syngal et al examined the performance of existing clinical criteria for HNPCC in identifying and excluding mutations in MSH2/MLH1 and found the Amsterdam criteria to be insufficiently sensitive (61\%) and specific $(67 \%)$ to be used as the sole criterion for identifying which families should undergo genetic testing; as in our study, increasing the sensitivity of criteria was associated with reduced specificity [22].
Selection of cases using the Bethesda criteria should be supplemented with further tumour based analyses as described however there are a variety of possible barriers to this approach including practical, ethical and technical difficulties. Practical problems include retention of tissues in pathology laboratories, method of preservation of archival tissues, willingness of hospitals to locate and release material and the current uncertainties (particularly 
Table 2b. Detected MSH2 mutations, clinical details and results of MSI and IHC analyses

\begin{tabular}{|c|c|c|c|c|c|c|c|c|}
\hline $\begin{array}{l}\text { clinical } \\
\text { criteria }\end{array}$ & $\begin{array}{l}\text { colon } \\
\text { cancer } \\
\text { total }\end{array}$ & $\begin{array}{c}\text { colon } \\
\text { cancer } \\
\text { average }\end{array}$ & $\begin{array}{c}\text { MS } \\
\text { status } \\
\text { age }\end{array}$ & $\begin{array}{c}\text { loss } \\
\text { MLH1 } \\
\text { expression }\end{array}$ & $\begin{array}{c}\text { loss } \\
\text { MSH2 } \\
\text { expression }\end{array}$ & $\begin{array}{l}\text { mutation } \\
\text { type }\end{array}$ & pathogenic & $\begin{array}{c}\mathrm{MSH} 2 \\
\text { mutation }\end{array}$ \\
\hline A & 2 & 47 & ND & ND & ND & stop & yes & $1072 \mathrm{G}>\mathrm{T}$ \\
\hline$A$ & 4 & 46 & ND & ND & ND & frameshift & yes & 1578delC \\
\hline$A$ & 3 & 53 & ND & ND & ND & frameshift & yes & $1577 \mathrm{delC}$ \\
\hline A & 3 & 46 & MSI & ND & ND & frameshift & yes & $2502-2508$ del \\
\hline A & 3 & 40 & ND & ND & ND & frameshift & yes & $1059 \mathrm{delG}$ \\
\hline A & 3 & 46 & ND & ND & ND & frameshift & yes & 1986delAG \\
\hline A & 3 & 45 & ND & ND & ND & splice site mutation & yes & $942+3 A>T$ \\
\hline$A$ & 6 & 38 & MSS & No & Yes & splice site mutation & yes & $942+3 A>T$ \\
\hline A & 8 & 45 & ND & ND & ND & stop & yes & $1165 C>T$ \\
\hline$A$ & 3 & 44 & ND & ND & ND & frameshift & yes & $2481 \mathrm{delG}$ \\
\hline$A$ & 3 & 36 & ND & ND & ND & stop & yes & $351 G>A$ \\
\hline$A$ & 2 & 40 & ND & ND & ND & frameshift & yes & 526delC \\
\hline$A$ & 3 & 50 & ND & ND & ND & large deletion & yes & exon 1del \\
\hline$A$ & 3 & 49 & MSS & No & Yes & lge del & yes & exons 1-2del \\
\hline A & 3 & 57 & ND & ND & ND & missense & NK & $1760-62 G>A$ \\
\hline$A$ & 4 & 44 & MSI & No & Yes & frameshift & yes & 1218insTACCG \\
\hline$A$ & 3 & 38 & MSS & No & Yes & lge del & yes & exons 9-16del \\
\hline A & 3 & 36 & MSI & No & Yes & lge del & yes & exons 4-16del \\
\hline$A$ & 8 & 46 & MSS & No & Yes & frameshift & yes & 924delAG \\
\hline $\mathrm{A} 2$ & 3 & 57 & MSI & No & Yes & frameshift & yes & $680-716$ dup \\
\hline $\mathrm{A} 2$ & 2 & 56 & MSS & No & No & missense & polymorphism & $965 G>A$ \\
\hline $\mathrm{A} 2$ & 2 & 47 & ND & ND & ND & stop & yes & $1072 \mathrm{G}>\mathrm{T}$ \\
\hline B1-3 & 2 & 23 & MSI & No & Yes & lge del & yes & exons 9-16del \\
\hline B1-3 & 1 & 43 & MSI & No & Yes & missense & NK & $817 \mathrm{G}>\mathrm{A} \& 818 \mathrm{~T}>\mathrm{A}$ \\
\hline B 1-3 & 2 & 47 & MSS & No & No & missense & polymorphism & $2006-6 T>C$ \\
\hline B4-7 & 1 & 26 & ND & ND & ND & stop & yes & $1609 A>T$ \\
\hline B4-7 & 1 & 41 & MSS & No & Yes & large deletion & yes & exons 1-8del \\
\hline MA & 3 & 45 & ND & ND & ND & frameshift & yes & 2501-2507 del \\
\hline MA & 2 & 52 & ND & ND & ND & nonsense & yes & $2038 C>T$ \\
\hline MA & 4 & 51 & ND & ND & ND & splice & yes & $943-1 G>A$ \\
\hline MA & 3 & 70 & ND & ND & ND & frameshift & yes & 2634insT + delGGTTTGTCAG \\
\hline MA & 2 & 42 & ND & No & Yes & lge del & yes & exons4-16del \\
\hline MA & 2 & 47 & ND & ND & ND & splice mutation & yes & $942+3 A>T$ \\
\hline
\end{tabular}

A - meets the full Amsterdam criteria; A2 - meets the Amsterdam 2 criteria; B - meets the Bethesda guidelines (1-3, 4-7);

$M A$ - meets the modified Amsterdam criteria; ND - not done; NK - not known 
Table 3. Sensitivity and specificity of clinical criteria for identifying kindreds with pathogenic MSH2 or MLH1 mutations

\begin{tabular}{|c|c|c|c|c|c|c|}
\hline Clinical criteria & $\begin{array}{l}\text { Number } \\
\text { of families } \\
\text { fulfilling } \\
\text { criteria }\end{array}$ & $\begin{array}{c}\text { No of families } \\
\text { with } M S H 2 \\
\text { or MLH1 } \\
\text { mutations }\end{array}$ & $\begin{array}{c}\text { Families } \\
\text { with mutations } \\
\text { missed } \\
\text { by criteria }\end{array}$ & $\begin{array}{c}\text { Sensitivity } \\
\text { (95\% confidence } \\
\text { intervals) }\end{array}$ & $\begin{array}{c}\text { Specificity } \\
\text { (95\% confidence } \\
\text { intervals) }\end{array}$ & $\begin{array}{c}\text { Positive } \\
\text { predictive value } \\
\text { (95\% confidence } \\
\text { intervals) }\end{array}$ \\
\hline Amsterdam & 53 & 30 & 19 & $61 \%(46-74 \%)$ & $74 \% \quad(65-82 \%)$ & $57 \%(43-69 \%)$ \\
\hline Modified Amsterdam & 65 & 37 & 12 & $76 \%(62-87 \%)$ & $69 \%(58-78 \%)$ & $57 \%(45-68 \%)$ \\
\hline Amsterdam II & 67 & 39 & 10 & $80 \%(66-90 \%)$ & $69 \%(58-78 \%)$ & $58 \%(46-69 \%)$ \\
\hline Bethesda 1-3 & 99 & 45 & 4 & $92 \%(81-97 \%)$ & $39 \%(30-50 \%)$ & $46 \%(36-55 \%)$ \\
\hline Bethesda all & 136 & 49 & 0 & $100 \%$ (93-100\%) & $2 \%(0-7 \%)$ & $36 \%(28-44 \%)$ \\
\hline
\end{tabular}

at this time in the UK) about consent. These were all barriers we experienced in retrieving suitable tissue for this study. Technically MSI analysis involves DNA extraction from archival paraffin-embedded blocks which is labour-intensive and time-consuming and yields variable quality. We chose to use a single, reportedly highly sensitive monoallelic repeat marker for instability testing because the costs were equivalent to the cost of performing immunohistochemistry. However our data show that the sensitivity of BAT26 alone is disappointing and future work using the currently recommended panel of markers would be likely to improve sensitivity [1 1].

Immunohistochemistry is relatively inexpensive and easy to perform on paraffin blocks. One disadvantage of $\mathrm{IHC}$ is that not all laboratories achieve robust and reproducible results so it may not be an option in every centre [23]. Also, IHC cannot achieve $100 \%$ sensitivity in the detection of mutations because of the occurrence of some types of mutation may lead to a non-functional protein but retention of the antigen binding epitopes. However an important advantage of IHC over MSI analysis is to indicate which MMR gene should be analysed for a germline mutation. The ability to compare tumour nuclear staining with stromal tissue and adjacent non-neoplastic tissue in all cases provides a robust internal control for comparisons. Recent work has highlighted the importance of extending $\mathrm{IHC}$ analysis to include MSH6 and PMS2 [24]. Although these were not included in this analysis, we would anticipate that inclusion of these would improve mutation detection without greatly increasing the cost of analysis.

Previous studies have examined the use of $\mathrm{IHC}$ in tumours associated with MMR gene defects. Lindor et al compared MSI analysis with IHC detection of MLHI and MSH2 in 1144 colorectal cancers and found that IHC provided a sensitive (92.3\%) and specific (100\%) method for predicting the presence of MSI but germline mutations in DNA mismatch repair genes were not looked at [25].

Debniak et al evaluated the significance of pedigree/clinical data, IHC and MSI analysis in reducing the cost of determining $\mathrm{MLH1} / \mathrm{MHS} 2$ gene mutations in 25 patients with colorectal cancer. They found that the greatest reduction of costs in the detection of one mutation was achieved when genetic testing was limited to the evaluation of pedigree/clinical data and IHC, although in such a diagnostic model some mutations can be missed [26]. Our data agree with the conclusions of these authors.

In summary, the results of our study indicate that the strategy achieving the highest sensitivity for the lowest cost in the identification of MLH1 and MSH2 germline mutations is to use sensitive clinical criteria followed by IHC on tumour blocks and when this is normal, MSI analysis. If tumour tissue is not available, it is more cost effective to use more stringent clinical criteria such as the Modified Amsterdam criteria. The availability of tumour tissue blocks and experience in the diagnostic laboratory in these additional tumour based tests can maximise cost effectiveness of mutation searching in HNPCC.

\section{Acknowledgements}

We are grateful to Nathan Coombes and Mark Coleman for extracting DNA from some of the tumour samples, Sophie Pilkington for some data collection and Ron Lee for IHC slide preparation.

\section{Conflict of interest statement}

There are no conflicts of interest for any of the authors.

\section{Funding source}

This work was funded by grants from the South West Research and Development Office and HOPE. 
Table 4. Cost analysis using preselection by clinical criteria and IHC and/or MSI analysis for cases where all three tests could be applied

\begin{tabular}{|c|c|c|c|c|c|c|c|c|}
\hline & $\begin{array}{l}\text { Method } \\
\text { of preselection } \\
\text { (no of cases studied) }\end{array}$ & $\begin{array}{l}\text { Total cases } \\
\text { selected } \\
\text { for testing }\end{array}$ & $\begin{array}{c}\text { No } \\
\text { of genes }\end{array}$ & $\begin{array}{l}\text { Total } \\
\text { tests }\end{array}$ & $\begin{array}{l}\text { Total } \\
\text { mutations } \\
\text { detected }\end{array}$ & $\begin{array}{l}\text { Mutations } \\
\text { missed } \\
\text { by selecting }\end{array}$ & $\begin{array}{l}\text { Cost } \\
\text { per mutation } \\
\text { detected } \\
\text { (euros) }\end{array}$ & \\
\hline \multirow[t]{5}{*}{1} & $A C$ & 53 & 2 & 106 & 30 & 19 & 1767 & 1 \\
\hline & MA & 65 & 2 & 130 & 37 & 12 & 1844 & \\
\hline & B1-3 & 99 & 2 & 198 & 45 & 4 & 2200 & \\
\hline & B & 136 & 2 & 272 & 49 & 0 & 2776 & \\
\hline & Any CC & 138 & 2 & 276 & 49 & 0 & 2816 & \\
\hline \multirow[t]{5}{*}{2} & $A C+I H C(23)$ & 12 & 1 & 12 & 10 & 9 & 715 & 2 \\
\hline & $M A+I H C(24)$ & 13 & 1 & 13 & 10 & 9 & 770 & \\
\hline & $\mathrm{Bl}-3+\mathrm{IHC}(42)$ & 20 & 1 & 20 & 14 & 5 & 864 & \\
\hline & $B+I H C(63)$ & 28 & 1 & 28 & 16 & 3 & 1072 & \\
\hline & Any CC+IHC (64) & 28 & 1 & 28 & 16 & 3 & 1075 & \\
\hline \multirow[t]{5}{*}{3} & $A C+M S I(24)$ & 11 & 2 & 22 & 8 & 5 & 1525 & 3 \\
\hline & $M A+M S I(25)$ & 11 & 2 & 22 & 8 & 5 & 1531 & \\
\hline & $\mathrm{B} 1-3+\mathrm{MSI}(40)$ & 18 & 2 & 36 & 13 & 5 & 1666 & \\
\hline & $B+M S I(59)$ & 23 & 2 & 46 & 13 & 6 & 1996 & \\
\hline & All CC+MSI (60) & 23 & 2 & 46 & 13 & 6 & 2000 & \\
\hline \multirow[t]{5}{*}{4} & $\mathrm{~A}+\mathrm{IHC}+\mathrm{MSI}(21)$ & $\begin{array}{r}11 \\
2\end{array}$ & $\begin{array}{l}1 \\
2\end{array}$ & 15 & 10 & 6 & 855 & \\
\hline & $M A+I H C+M S I(22)$ & $\begin{array}{r}12 \\
2\end{array}$ & $\begin{array}{l}1 \\
2\end{array}$ & 16 & 10 & 6 & 910 & \\
\hline & $\mathrm{B} 1-3+\mathrm{IHC}+\mathrm{MSI}(36)$ & $\begin{array}{r}16 \\
5\end{array}$ & $\begin{array}{l}1 \\
2\end{array}$ & 26 & 14 & 2 & 1057 & \\
\hline & $\mathrm{B}+\mathrm{IHC}+\mathrm{MSI}(54)$ & $\begin{array}{r}24 \\
6\end{array}$ & $\begin{array}{l}1 \\
2\end{array}$ & 36 & 16 & 0 & 1294 & \\
\hline & All CC+IHC+MSI (55) & $\begin{array}{r}24 \\
6\end{array}$ & $\begin{array}{l}1 \\
2\end{array}$ & 36 & 16 & 0 & 1297 & \\
\hline
\end{tabular}

\section{References}

1. Aaltonen LA, Salovaara R, Kristo P, Canzian F, Hemminki A, Peltomaki P Chadwick RB, Kaariainen $H$, Eskelinen M, Jarvinen H, Mecklin JP and de la Chapelle A. Incidence of hereditary nonpolyposis colorectal cancer and the feasibility of molecular screening for the disease. N Engl J Med 1998; 338: 1481-1487.

2. Liu B, Parsons R, Papadopoulos N, Nicolaides NC, Lynch HT, Watson P, Jass JR, Dunlop M, Wyllie A, Peltomaki P, de la Chapelle A, Hamilton SR, Vogelstein B and Kinzler KW. Analysis of mismatch repair genes in hereditary non-polyposis colorectal cancer patients. Nat Med 1996; 2: 169-174.
3. Nystrom-Lahti M, Wu Y, Moisio AL, Hofstra RM, Osinga J, Mecklin JP, Jarvinen HJ, Leisti J, Buys $\mathrm{CH}$, de la Chapelle A and Peltomaki P. DNA mismatch repair gene mutations in 55 kindreds with verified or putative hereditary non-polyposis colorectal cancer. Hum Mol Genet 1996; 5: 763-769.

4. Jarvinen HJ, Aarnio M, Mustonen H, Aktan-Collan K, Aaltonen LA, Peltomaki P, De La Chapelle A and Mecklin JP. Controlled 15-year trial on screening for colorectal cancer in families with hereditary nonpolyposis colorectal cancer. Gastroenterology 2000; 1 18: 829-834.

5. Percesepe A, Anti M, Marra G, Roncucci L, Pahor M, Coco C, Armelao F, Gasbarrini $G$ and Ponz de Leon M. Role of clinical criteria in the diagnosis of hereditary non-polyposis colorectal 
cancer (HNPCC): results of a multivariate analysis. Int J Cancer 1994; 58: 799-802.

6. Vasen HF, Mecklin JP, Khan PM and Lynch HT. The International Collaborative Group on Hereditary Non-Polyposis Colorectal Cancer (ICG-HNPCC). Dis Colon Rectum 1991; 34: 424-425.

7. Marra $G$ and Boland CR. Hereditary nonpolyposis colorectal cancer: the syndrome, the genes, and historical perspectives. J Natl Cancer Inst 1995; 87: 1114-1125.

8. Bellacosa A, Genuardi M, Anti M, Viel A and Ponz DL. Hereditary nonpolyposis colorectal cancer: review of clinical, molecular genetics, and counseling aspects. Am J Med Genet 1996; 62: 353-364.

9. Rodriguez-Bigas MA, Boland $C R$, Hamilton $S R$, Henson DE, Jass $J R$, Khan PM, Lynch H, Perucho M, Smyrk T, Sobin L and Srivastava S. A National Cancer Institute Workshop on Hereditary Nonpolyposis Colorectal Cancer Syndrome: meeting highlights and Bethesda guidelines. J Natl Cancer Inst 1997; 89: 1758-1762

10. Vasen HF, Watson P, Mecklin JP and Lynch HT. New clinical criteria for hereditary nonpolyposis colorectal cancer (HNPCC, Lynch syndrome) proposed by the International Collaborative Group on HNPCC. Gastroenterology 1999; 116: 1453-1456.

11. Umar A, Boland CR, Terdiman JP, Syngal S, de la CA, Ruschoff J, Fishel R, Lindor NM, Burgart LJ, Hamelin R, Hamilton SR, Hiatt RA, Jass J, Lindblom A, Lynch HT, Peltomaki P, Ramsey SD, Rodriguez-Bigas MA, Vasen HF, Hawk ET, Barrett JC, Freedman AN and Srivastava S. Revised Bethesda Guidelines for hereditary nonpolyposis colorectal cancer (Lynch syndrome) and microsatellite instability. J Natl Cancer Inst 2004; 96: 261-268.

12. Aaltonen LA, Peltomaki P, Mecklin JP, Jarvinen H, Jass JR, Green JS, Lynch HT, Watson P, Tallquist G, Juhola M, Sistonen P, Hamilton S, Kinzler KW, Vogelstein B and de la Chapelle A. Replication errors in benign and malignant tumors from hereditary nonpolyposis colorectal cancer patients. Cancer Res 1994; 54: 1645-1648.

13. Bocker T, Diermann J, Friedl W, Gebert J, Holinski-Feder E, Karner-Hanusch J, von Knebel-Doeberitz M, Koelble K, Moeslein G, Schackert HK, Wirtz HC, Fishel R and Ruschoff J. Microsatellite instability analysis: a multicenter study for reliability and quality control. Cancer Res 1997; 57: 4739-4743.

14. Cunningham JM, Kim CY, Christensen ER, Tester DJ, Parc Y, Burgart LJ, Halling KC, McDonnell SK, Schaid DJ, Walsh Vockley C, Kubly V, Nelson H, Michels VV and Thibodeau SN. The frequency of hereditary defective mismatch repair in a prospective series of unselected colorectal carcinomas. Am J Hum Genet 2001; 69: 780-790.

15. Boland CR, Thibodeau SN, Hamilton SR, Sidransky D, Eshleman JR, Burt RW, Meltzer SJ, Rodriguez-Bigas MA, Fodde R, Ranzani GN and Srivastava S. A National Cancer Institute Workshop on Microsatellite Instability for cancer detection and familial predisposition: development of international criteria for the determination of microsatellite instability in colorectal cancer. Cancer Res 1998; 58: 5248-5257.

16. Samowitz WS, Slattery ML, Potter JD and Leppert MF. BAT-26 and BAT-40 instability in colorectal adenomas and carcinomas and germline polymorphisms. Am J Pathol 1999; 154: 1637-1641.

17. Hoang JM, Cottu PH, Thuille B, Salmon RJ, Thomas G and Hamelin R. BAT-26, an indicator of the replication error phenotype in colorectal cancers and cell lines. Cancer Res 1997; 57: 300-303.

18. Loukola A, Eklin K, Laiho P, Salovaara R, Kristo P, Jarvinen H, Mecklin JP, Launonen V and Aaltonen LA. Microsatellite marker analysis in screening for hereditary nonpolyposis colorectal cancer (HNPCC). Cancer Res 2001; 61: 4545-4549.
19. Marcus VA, Madlensky L, Gryfe R, Kim H, So K, Millar A, Temple LK, Hsieh E, Hiruki T, Narod S, Bapat BV, Gallinger S and Redston M. Immunohistochemistry for hMLH1 and hMSH2: a practical test for DNA mismatch repair-deficient tumors. Am J Surg Pathol 1999; 23: 1248-1255.

20. Stone JG, Robertson D and Houlston RS. Immunohistochemistry for MSH2 and MHL1: a method for identifying mismatch repair deficient colorectal cancer. J Clin Pathol 2001; 54: 484-487.

21. Holinski-Feder E, Muller-Koch Y, Friedl W, Moeslein G, Keller G, Plaschke J, Ballhausen W, Gross M, Baldwin-Jedele K, Jungck M, Mangold E, Vogelsang H, Schackert HK, Lohsea P, Murken J and Meitinger T. DHPLC mutation analysis of the hereditary nonpolyposis colon cancer (HNPCC) genes hMLH1 and hMSH2. J Biochem Biophys Methods 2001; 47: $21-32$.

22. Syngal S, Fox EA, Eng C, Kolodner RD and Garber JE. Sensitivity and specificity of clinical criteria for hereditary non-polyposis colorectal cancer associated mutations in MSH2 and MLH1. J Med Genet 2000; 37: 641-645.

23. Muller W, Burgart LJ, Krause-Paulus R, Thibodeau SN, Almeida M, Edmonston TB, Boland CR, Sutter C, Jass JR, Lindblom A, Lubinski J, MacDermot K, Sanders DS, Morreau H, Muller A, Oliani C, Orntoft T, Ponz De Leon M, Rosty C, Rodriguez-Bigas M, Ruschoff J, Ruszkiewicz A, Sabourin J, Salovaara R, Moslein G; ICG-HNPCC (International Collaborative Group). The reliability of immunohistochemistry as a prescreening method for the diagnosis of hereditary nonpolyposis colorectal cancer (HNPCC) -results of an international collaborative study. Fam Cancer 2001; 1: 87-92.

24. de Jong $A E$, van Puijenbroek $M$, Hendriks $Y$, Tops $C$, Wijnen J, Ausems MGEM, Meijers-Heijboer H, Wagner A, van Os TA, Brocker-Vriends AH, Vasen HF and Morreau H. Microsatellite instability, immunohistochemistry, and additional PMS2 staining in suspected hereditary nonpolyposis colorectal cancer. Clin Cancer Res 2004; 10: 972-980.

25. Lindor NM, Burgart $L$, Leontovich $O$, Goldberg RM, Cunningham $J M$, Sargent DJ, Walsh-Vockley C, Petersen GM, Walsh MD, Leggett BA, Young JP, Barker MA, Jass JR, Hopper J, Gallinger S, Bapat B, Redston M and Thibodeau SN. Immunohistochemistry versus microsatellite instability testing in phenotyping colorectal tumors. J Clin Oncol 2002; 20: 1043-1048.

26. Debniak T, Kurzawski G, Gorski B, Kladny J, Domagala W and Lubinski J. Value of pedigree/clinical data, immunohistochemistry and microsatellite instability analyses in reducing the cost of determining $\mathrm{hMLH} 1$ and $\mathrm{hMSH} 2$ gene mutations in patients with colorectal cancer. Eur J Cancer 2000; 36: 49-54. 